\title{
INFRARED SPECTROSCOPY OF INTERSTELLAR AND SOLAR SYSTEM ICE ANALOGS: MEASUREMENT OF OPTICAL CONSTANTS
}

\author{
D.M. Hudgins, S.A. Sandford, A.G.G.M. Tielens, and L.J. Allamandola \\ NASA/Ames Research Center, MS 245-6, Moffett Field, CA, 94035
}

\begin{abstract}
Laboratory spectra through the mid-infrared have been used to calculate the optical constants ( $\mathrm{n}$ and $\mathrm{k}$ ) for a variety of pure and mixed molecular ices. The ices studied were $\mathrm{H}_{2} \mathrm{O}, \mathrm{CH}_{3} \mathrm{OH}, \mathrm{CO}_{2}, \mathrm{OCS}, \mathrm{CH}_{4}, \mathrm{CO}_{2}+\mathrm{CH}_{4}, \mathrm{CO}_{2}+\mathrm{OCS}, \mathrm{CO}+\mathrm{CH}_{4}, \mathrm{CO}+\mathrm{OCS}$, $\mathrm{O}_{2}+\mathrm{CH}_{4}, \mathrm{O}_{2}+\mathrm{OCS}, \mathrm{N}_{2}+\mathrm{CH}_{4}, \mathrm{~N}_{2}+\mathrm{OCS}, \mathrm{H}_{2} \mathrm{O}+\mathrm{CH}_{4}, \mathrm{H}_{2} \mathrm{O}+\mathrm{OCS}$, and $\mathrm{H}_{2} \mathrm{O}+\mathrm{CH}_{3} \mathrm{OH}+\mathrm{CO}+\mathrm{NH}_{3}$.
\end{abstract}

\section{Introduction}

Band shapes, positions, and strengths in the absorption spectrum of a mixed molecular ice are diagnostic of the composition, temperature, and thermal history of that ice. ${ }^{1}$ Particle properties such as size, shape, and morphology (e.g. pure versus core/mantle particles) may also induce observable variations. ${ }^{2}$ Consequently, absorption spectra carry a great deal of information about the nature of ices in a variety of astronomical environments. Through detailed modelling using the pertinent optical constants it is often possible to deconvolve the factors affecting the observed spectra. In the laboratory it is necessary to study the mixtures of interest since the n's and k's for a mixed molecular ice are not given by the weighted sum of the n's and k's of each ice component in its pure form. Such an approach fails to account for the unique intermolecular interactions which occur between different molecules in a mixed solid.

\section{Technique}

The experiment involves an infrared window suspended from a cryogenically cooled cold finger in a high vacuum chamber. A thin layer of ice is layed down by vapor deposition onto the cooled window. Sample thickness is monitored by the interference fringes observed in a HeNe laser beam reflected off the front of the window during sample deposition. After deposition is complete, the sample is rotated under vacuum to face the infrared beam and spectra are collected as a function of ice temperature. The results were obtained through an iterative application of the Kramers-Kronig relation. A hypothetical set of $n$ 's and k's were used to calculate a theoretical transmission spectrum. This, in turn, was compared to the actual spectrum, and the set of $n$ 's and k's were corrected for any deviations between the two. This process was repeated until the maximum calculated deviation was less than $0.1 \%$. 


\section{Results}

We have derived optical constants for the following ices: Pure substances: $\mathrm{H}_{2} \mathrm{O}$ (water), $\mathrm{CH}_{3} \mathrm{OH}$ (methanol), $\mathrm{CO}_{2}$ (carbon dioxide), $\mathrm{OCS}$ (carbonyl sulfide), and $\mathrm{CH}_{4}$ (methane); Binary mixtures: $\mathrm{CO}_{2}: \mathrm{CH}_{4}=20: 1, \mathrm{CO}_{2}: \mathrm{OCS}=20: 1, \mathrm{CO}: \mathrm{CH}_{4}=20: 1, \mathrm{CO}: \mathrm{OCS}=20: 1$, $\mathrm{O}_{2}: \mathrm{CH}_{4}=20: 1, \mathrm{O}_{2}: \mathrm{OCS}=20: 1, \mathrm{~N}_{2}: \mathrm{CH}_{4}=20: 1, \mathrm{~N}_{2}: \mathrm{OCS}=20: 1, \mathrm{H}_{2} \mathrm{O}: \mathrm{CH}_{4}=20: 1$, $\mathrm{H}_{2} \mathrm{O}: \mathrm{OCS}=20: 1$, and $\mathrm{H}_{2} \mathrm{O}: \mathrm{OCS}=2: 1$; Interstellar mixtures:

$\mathrm{H}_{2} \mathrm{O}: \mathrm{CH}_{3} \mathrm{OH}: \mathrm{CO}: \mathrm{NH}_{3}=100: 50: 1: 1$ and $\mathrm{H}_{2} \mathrm{O}: \mathrm{CH}_{3} \mathrm{OH}: \mathrm{CO}: \mathrm{NH}_{3}=100: 10: 1: 1$. An example is shown in figure 1 . The results will be presented in a future paper. ${ }^{3}$

\section{References}

(1) Sandford, S.A., Allamandola, L.J., Tielens, A.G.G.M., and Valero, G.J., Ap.J., 329, 498 (1988)

(2) Tielens, A.G.G.M., Tokunaga, A.T., Geballe. T.R., and Baas, F., Ap.J., (in press) 1 November, 1991

(3) Hudgins, D.M., Sandford, S.A., Tielens, A.G.G.M., and Allamandola, L.J., Ap.J.Supp.Ser., (in preparation)
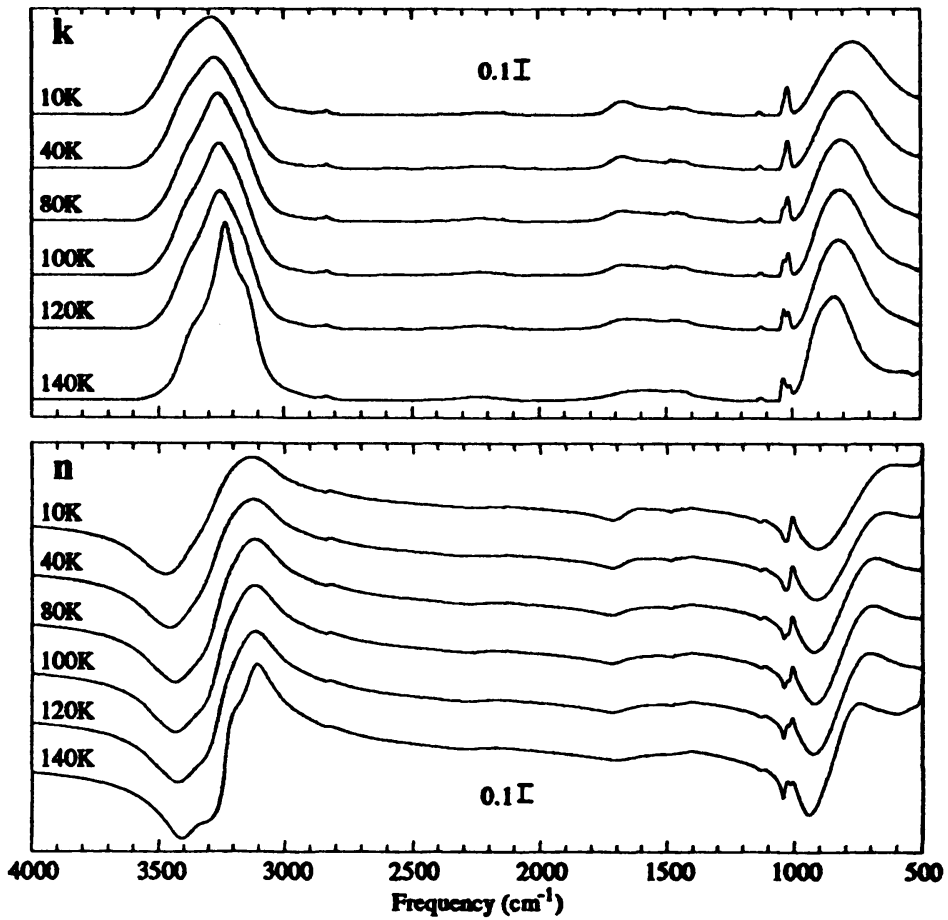

Figure 1. $\mathrm{k}$ and $\mathrm{n}$ values for the ice mixture $\mathrm{H}_{2} \mathrm{O}: \mathrm{CH}_{3} \mathrm{OH}: \mathrm{CO}: \mathrm{NH}_{3}=100: 10: 1: 1$ 